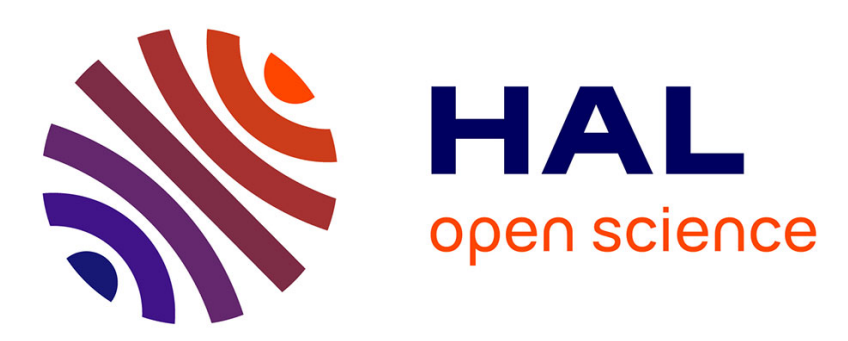

\title{
Soil macroaggregate dynamics in a mountain spatial climate gradient
}

Lauric Cécillon, Nilvania A. de Mello, Sébastien de Danieli, Jean-Jacques Brun

\section{To cite this version:}

Lauric Cécillon, Nilvania A. de Mello, Sébastien de Danieli, Jean-Jacques Brun. Soil macroaggregate dynamics in a mountain spatial climate gradient. Biogeochemistry, 2010, 97 (1), pp.31-43. 10.1007/s10533-009-9341-9 . hal-00397057v3

\section{HAL Id: hal-00397057 \\ https://hal.science/hal-00397057v3}

Submitted on 23 Jan 2010

HAL is a multi-disciplinary open access archive for the deposit and dissemination of scientific research documents, whether they are published or not. The documents may come from teaching and research institutions in France or abroad, or from public or private research centers.
L'archive ouverte pluridisciplinaire HAL, est destinée au dépôt et à la diffusion de documents scientifiques de niveau recherche, publiés ou non, émanant des établissements d'enseignement et de recherche français ou étrangers, des laboratoires publics ou privés. 


\section{Soil macroaggregate dynamics}

\section{in a mountain spatial climate gradient}

Lauric Cécillon ${ }^{1,2, *}$, Nilvania A. de Mello ${ }^{3}$, Sébastien De Danieli ${ }^{1}$, Jean-Jacques Brun ${ }^{1}$

Affiliations:

${ }^{1}$ Cemagref Grenoble, Mountain Ecosystems Research Unit, 2 rue de la Papeterie, BP 76, 38402 Saint Martin d'Hères, France

${ }_{2}^{2}$ French Agency for Environment and Energy Management (ADEME), 2 square La Fayette, BP 90406, 49004 Angers cedex 01, France

${ }^{3}$ Federal University of Technology, Paraná, Via do Conhecimento, Km 01, PO box 571,ZIP code 85503-390, Pato Branco, PR, Brazil

Address for correspondence:

*corresponding author: L. Cécillon

Present address: CETIOM Paris-Grignon, UMT GES- $\mathrm{N}_{2} \mathrm{O}$, Avenue Lucien Brétignières, 78850 Thiverval-Grignon, France

Phone: +33 (0)130 799 564; Fax: +33 (0)130 799 590; E-mail : cecillon@cetiom.fr; Webpage : http://lauric.cecillon.free.fr/

Key words: Mountain soils; Climate change; Soil aggregation; Soil organic matter;

Near infrared reflectance spectroscopy; Soil threats 


\section{Abstract}

We investigated the response of soil macroaggregate dynamics to soil temperature modification along a spatial gradient located on a forested north-facing slope in the southern French Alps, simulating long-term adjustment of soil-plant interactions to absence or occurrence of soil frost. Soil macroaggregate (> $250 \mu \mathrm{m})$ content of Ah horizons was strongly depleted $(72 \%)$ in colder plots affected by freeze-thaw events, compared to $96 \%$ in warmer and frost-free plots $(p<0.05)$. A visual assessment of soil macroaggregation showed that physical processes were the main drivers of soil macroaggregation in colder plots, with $66 \%$ of the $5-12.5 \mathrm{~mm}$ fraction and the whole $3.15-5 \mathrm{~mm}$ fraction. Conversely, we found a balanced contribution of biological and physical aggregation pathways in warmer plots. All identified macroaggregate types could be classified, depending on their organic matter (OM) quality, using principal component analyses of their near infrared spectra. Such spectral classifications indicated temporal changes in $\mathrm{OM}$ quality of macroaggregates, from formation to colonization by fine roots, suggesting ecosystem-specific ontogenic trajectories for soil macroaggregation. Further physico-chemical characterizations of soil macroaggregates and Ah horizons showed that soil organic carbon content in the Ah horizon was constant along the gradient, whereas soil erodibility was reduced in warmer soils, which prevented the occurrence of fragile macroaggregates formed by freeze-thaw events. Our study thus suggests changes in the erodibility of mountain forest soils under changing climate. Soil erodibility could be affected either positively under warmer conditions, or negatively, under increased soil frost. 


\section{Introduction}

Mountain regions occupy about a quarter of the global land surface and provide goods and services to more than half of humanity (Huber et al. 2005). High-elevation soils are key resources which provide most of these beneficial services, supporting agro-sylvo-pastoral production systems through nutrient cycling, biodiversity, primary production and water supply. In mountain areas, rising or cooling temperatures and extreme weather events are expected to alter spatial and temporal patterns of snow cover, leading to increases in soil freezing (Groffman et al. 2001; Edwards et al. 2007). Such changes in soil frost are likely to modify greenhouse gas emissions and exacerbate threats such as organic matter decline, soil erodibility, and decline of soil biodiversity (European Commission 2006; Groffman et al. 2006; Cassagne et al. 2008; Matzner and Borken 2008). These soil threats are closely associated with possible changes in certain soil processes under a changing climate. Although the fate of soil organic matter decomposition in cold areas and its interaction with the living soil has received much scientific attention in the last two decades (Heimann and Reichstein 2008), changes in soil aggregation process could also have a dramatic influence on each above-mentioned threat to mountain soils involving feedback to climate change (Young et al. 1998; Bronick and Lal 2005; Matzner and Borken 2008).

Soil aggregation processes comprise all mechanisms involved in the binding of soil particles into stable aggregates, which are the basic unit of structure in soils (Lavelle and Spain 2001). Soil aggregates mediate soil functioning in various ways which have profound effects on soil organic matter (SOM) dynamics, nutrient cycling and soil biodiversity. Aggregates physically protect soil organic matter and soil aggregation is considered the nucleus of all mechanisms of carbon sequestration (Blanco-Canqui and Lal 2004). Soil aggregates also regulate water flow, reduce run-off and erosion through their stability and comprises habitat for soil organisms (Barthès and Roose 2002). The complex dynamics of aggregation are the result of the interaction of many driving factors including soil management, inorganic binding agents, soil fauna, roots, microorganisms and environmental variables (Six et al. 2004). For instance, increases in soil freezing can induce disruption of soil aggregates (Groffman et al. 2006; Kværnø and Øygarden 
2006). Two main size classes of soil aggregates have been delineated (Bronick and Lal 2005) microaggregates $(<250 \mu \mathrm{m})$ and macroaggregates $(>250 \mu \mathrm{m})$. These size classes match the widespread aggregate hierarchy theory in which microaggregates are bound together to form large compound aggregates (Tisdall and Oades 1982). Different macroaggregate types can be discriminated using a non-destructive visual approach, depending on their origin (biological or physical) and their age (Topoliantz et al. 2000; Pulleman et al. 2005). Each macroaggregate type is characterized by a specific physical, chemical and biological functioning, with associated microbial activity and SOM dynamics which can be assessed using near-infrared spectroscopy (NIRS; Hedde et al. 2005; Velasquez et al. 2007; Cécillon et al. 2009).

Hitherto, very few studies have addressed soil macroaggregation dynamics in mountain forest ecosystems. In the present study, we use a spatial climate gradient in the southern French Alps on soil macroaggregates of Ah horizons to simulate long-term effects of soil temperature modification under natural conditions. We propose a framework based on NIRS to assess the temporal dynamics of soil aggregation. Our framework is developed from the ecological concept of ontogeny of detritus described by Moore et al. (2004). This concept incorporates the heterogeneous nature of detritus and the changes it undergoes over time during decomposition or aggregation processes, which are explicitly represented by ontogenic trajectories (Moore et al. 2004). Near infrared spectroscopy is used as an operational tool for the assessment of the heterogeneity and ontogeny of soil macroaggregates. The objectives of this study were to: (i) identify specific pathways (i.e. trajectories) for soil macroaggregation under different soil microclimate conditions using visual identification and NIRS; and (ii) investigate the relationships of each identified aggregation pathway to soil threats such as declines in SOM and soil erosion. 


\section{Materials and methods}

Site description

We performed our experiment in the southern French Alps (Dévoluy Mountains). We selected a unique study site ( 5 ha), well protected for decades and minimally affected by human activities. This site was chosen in order to obtain a spatial climate gradient in which most state factors were kept constant (Amundson and Jenny 1997, see below), which helps to minimize sources of error when assessing forest soil processes (Lal 2005). Our site was located at Pellafol $\left(44^{\circ} 46^{\prime} \mathrm{N}\right.$ latitude, $5^{\circ} 52^{\prime} \mathrm{E}$ longitude), at an elevation of $1250 \mathrm{~m}$ a.s.l. in the Sapey forest (Pellafol, Isère, France; Asta et al. 2001), on a montane limestone scree. Mean annual air temperature and mean annual precipitation at the two nearest Météo France weather stations (Pellafol - Les Payas, 930 $\mathrm{m}$ a.s.I. and Saint Etienne en Dévoluy - Gendarmerie, $1300 \mathrm{~m}$ a.s.I.) are $8.6^{\circ} \mathrm{C}, 978 \mathrm{~mm}$ and $6.6^{\circ} \mathrm{C}, 1116 \mathrm{~mm}$, respectively.

The Pellafol site comprises (Garti 1980):

(a) Three open forest patches (0.5 ha each) of dwarf mountain pines (PF; Pinus uncinata). The understory of PF is dense and typical of cold areas with Empetrum nigrum, Vaccinium vitis-idaea, Dryas octopetala and a dense cover of lichens on Leptosols Eutric (IUSS Working Group WRB 2006; Legros 2007), with a very thick raw humus (Humus form = Tangel-Mor; Thickness of OF+OH > 20 cm; Brêthes et al. 1995; Cassagne et al. 2008).

(b) A beech-fir forest (BF; Fagus sylvatica and Abies alba), surrounding PF patches. The understory of BF is sparse and typical of a mountane forest, mainly composed of Vaccinium myrtillus and mosses on Leptosols Eutric (IUSS Working Group WRB 2006; Legros 2007), with a shallow humus layer (Humus form $=$ Moder; Thickness of $\mathrm{OF}+\mathrm{OH}<5 \mathrm{~cm}$; Brêthes et al. 1995). (c) A sharp (30 m width on average) ecotone (EC) between PF and BF, dominated by birches (Betula pubescens), with an understory mainly composed of Vaccinium vitis-idaea and Rhododendron ferrugineum on Leptosols Eutric with a thick raw humus, similar to the soil of PF. 
Previous studies of the Pellafol site have described soil microclimate as the main factor controlling the distribution of plant communities (Lambert 1967; Garti 1980). Air circulations between the limestone blocks create a paraglacial pedoclimate with seasonal soil frost in PF and EC (Lambert 1967; Asta et al. 2001). Respective mean annual soil temperature in Ah horizon at 30 cm depth $\left(T_{s}\right)$ of PF and EC are $-0.2^{\circ} \mathrm{C}$ and $+0.5^{\circ} \mathrm{C}$ (Figure 1), as measured by data loggers (Hobo, Onset Corporation). Conversely, in BF, soil microclimate is not affected by air circulations and $\mathrm{T}_{\mathrm{s}}$ rises to $+4.8^{\circ} \mathrm{C}$ with no soil freezing during winter (Figure 1). Ground thermal properties of such scree slopes have been extensively studied (Delaloye 2004). Even though snow is deeper and persists for a longer time (from November till April-May) in PF and EC, than in BF, soil frost occurs at $30 \mathrm{~cm}$ depth only in PF and EC, because of air circulations, and independently of snowpack depth (Delaloye et al. 2003). Such changes in frost intensity as well as the duration of soil frost correspond to expected climate change effects in most cold regions (Groffman et al. 2001; Matzner and Borken 2008). The Pellafol site could thus be used to study the effects of soil frost on soil aggregation process under natural conditions.

We selected nine research plots (each $20 \times 20 \mathrm{~m}$ ) within the Pellafol site: three plots in PF (each one in a separate forest patch), three plots in BF and three EC plots. All plots had a similar elevation with a slope of about $30 \%$ on similar north-facing limestone scree. In agreement with Amundson and Jenny (1997), our design allowed us to hold three state factors invariant (climate, topography and parent material), two state factors nearly constant (humans and time if we assume a steady state for forest ecosystems) and two state factors which differ between PF, BF and EC: soil microclimate and organisms (vegetation and soil food web). This carefully selected spatial climate gradient reflects long-term adjustments of ecosystems to local climate conditions, thereby simulating long-term effects of soil temperature modification on their processes like soil aggregation (Kueppers and Harte 2005; Becker et al. 2007). 
Sampling, pre-treatments and basic characteristics of Ah horizons

We studied soil macroaggregate dynamics in Ah horizons, which is the most similar soil horizon across the gradient. In October 2006, we dug five soil pits in each of the nine plots (soil profiles of about $0.7 \mathrm{~m}$ width and $0.5 \mathrm{~m}$ depth). We carefully collected intact soil aggregates from Ah horizons, between $25 \mathrm{~cm}$ and $35 \mathrm{~cm}$ depth in each profile, with a knife and a trowel. Most gravels or stones were removed by hand. This strategy allowed for the sampling of Ah horizons with neither contamination from above organic horizons nor compaction that usually occur with core sampling. Materials sampled in the five soil profiles were further merged into a unique composite sample representative of the heterogeneity of the plot. The nine composite samples from Ah horizons were immediately stored in rigid plastic boxes so as to preserve the integrity of soil aggregates. In one of the five soil pits of each plot, we collected one undisturbed volume of soil (8 $\times 5 \times 3 \mathrm{~cm}^{3}$ ) from the Ah horizon with a Kubiena box. The nine blocks of undisturbed soil were stored at $5^{\circ} \mathrm{C}$ before further processing.

Composite soil samples from Ah horizons were air-dried at room temperature. When necessary, clods were gently broken up along natural planes of weakness into aggregates $(<25$ $\mathrm{mm}$ ) and remaining stones, gravel and roots were removed as much as possible. Few aggregates that were disturbed due to sampling were discarded (Pulleman et al. 2005). Soil organic carbon (SOC) and total nitrogen $\left(\mathrm{N}_{\mathrm{t}}\right)$ content of Ah horizons were determined by dry combustion (NF ISO 10694 1995; NF ISO 13878 1998). Although carbonate content of all soil samples was low as revealed by treatment with acid, complete removal of carbonates was ensured through acid washing prior to all SOC measurements. Mineral nitrogen content $\left(\mathrm{N}-\mathrm{NO}_{3}\right.$ and $\left.\mathrm{N}-\mathrm{NH}_{4}\right)$ was determined following the method of Krom (1980). $\mathrm{pH}$ in $\mathrm{H}_{2} \mathrm{O}$ was measured according to NF ISO 10390 (2005). Cation exchange capacity (CEC) was determined by the Metson method (NF X 31130 1999). Exchangeable cations ( $\mathrm{Ca}, \mathrm{Mg}, \mathrm{K}, \mathrm{Na}$ ) were measured by atomic absorption spectroscopy after ammonium acetate extraction (NF X 31-108 2002). Base saturation (BS) was then computed as $\mathrm{BS}=100{ }^{*}[(\mathrm{Ca}+\mathrm{Mg}+\mathrm{K}+\mathrm{Na})$ / CEC $]$. Soil texture was determined according to NF X 31-107 (2003). Aggregate size distribution was established using a dry sieving 
apparatus as described in Pulleman et al. (2005), which is a preferable technique over wet sieving for preserving the integrity of soil aggregates (Blanco-Canqui and Lal 2004). Aggregates were sieved for 5 minutes over a stack of sieves with mesh sizes of $12.5 \mathrm{~mm}, 5 \mathrm{~mm}, 3.15 \mathrm{~mm}$ and 250 $\mu \mathrm{m}$, respectively. Macroaggregation was quantified by adding soil fractions above $250 \mu \mathrm{m}$.

Soil thin sections were made from the nine undisturbed blocks of Ah horizons which had been impregnated with synthetic resins (Fitzpatrick 1980). For each thin section, image acquisition was carried out in five windows of $20 \times 20 \mathrm{~mm}$ with a Sony Camera DXC-930P (spatial resolution of $18 \mu \mathrm{m} /$ pixel, spectral resolution of 256 grey levels) under a stereomicroscope using plain- and cross-polarized light. Soil porosity and stone content of Ah horizons were quantified by image analysis using ImageJ 1.38x software. Soil porosity corresponded to pixels which were white under plain-polarized light and black under cross-polarized light. Stones corresponded to white pixels under cross-polarized light.

Identification of aggregate fractions and macroaggregation pathways

We analysed macroaggregation pathways for two different size classes: $3.15-5 \mathrm{~mm}$ and $5-12.5$ $\mathrm{mm}$. We separated macroaggregates by hand under a stereomicroscope, according to the methodology described by Pulleman et al. (2005). We discriminated various morphological fractions from two main origins: a biological and a physical pathway. The biological pathway was characterized by biogenic aggregates with rounded shapes produced by soil fauna, often derived from earthworm casts (Rusek, 1985). Physical pathways were characterized by physicogenic aggregates with angular shapes, produced by physical processes like wet-dry or freeze-thaw cycles (Lavelle and Spain 2001). Biogenic and physicogenic aggregates were further discriminated into three classes depending on their age: young aggregates (i.e., freshly formed aggregates with clear structures and no visible macroporosity under stereomicroscope); aged aggregates (i.e., older aggregates with smoothed structures and a macroporosity visible under stereomicroscope); colonized aggregates (i.e. older aggregates strongly colonized by fine roots). Both biological and physical macroaggregation pathways were thus arranged in a chronosequence starting from 
freshly formed aggregates through to aged macroaggregates, and ultimately their colonization by fine roots. We further identified one category of aggregates associated with plant debris (APD).

We performed an additional assessment of aggregate fractions with NIRS so as to detect possible temporal changes in organic matter (OM) quality within each soil macroaggregation pathway (Joffre et al. 2001). Soil aggregates representative of all macroaggregates samples and identified under stereomicroscope were ground $(0.25 \mathrm{~mm})$ to obtain homogeneous powders and scanned (1000-2500 nm) with a near infrared (NIR) spectrophotometer Antaris II (Thermo electron). Each spectrum comprised 64 averaged scans of the sample. Data were collected at a 2 $\mathrm{nm}$ resolution resulting in 1557 absorbance values per spectrum.

\section{Basic characteristics of soil macroaggregates}

We measured various attributes of soil macroaggregates in order to quantify the specific contribution of each aggregation pathway to soil physical and chemical functioning along our gradient. As for Ah horizons samples, we measured SOC and $N_{t}$ content of all identified macroaggregate types. We also measured some mechanical properties of soil macroaggregates, which can control the mechanical behaviour of whole soil in relation to SOC sequestration (BlancoCanqui and Lal 2004). Bulk density and porosity of soil macroaggregates were respectively determined by dry weight of aggregates divided by aggregate volume and by water retention weight divided by aggregate volume ( $n=3$ for each aggregate type). For both calculations, aggregate volume was determined by displacement of water from aggregates which were previously water-proofed with a thin layer of cyanoacrylate (Kuczak et al. 2006). The susceptibility of soil aggregates to erosion (erodibility) was assessed using the method of Seybold and Herrick (2001), which quantifies the proportion of water stable aggregates (WSA) after a correction for sand content (remaining fraction $>250 \mu \mathrm{m}$ after wet-sieving in a solution of $10 \mathrm{~g} \mathrm{l}^{-1} \mathrm{Na}-$ hexametaphospate). For each aggregate type, particulate organic matter (POM) content, was also quantified using a wet-sieving technique derived from Cambardella and Elliott (1992). This labile pool of SOM consists of partially decomposed organic debris (Garten et al. 1999) and has been 
shown to be very sensitive to modifications of soil microclimate (Link et al. 2003). POM was obtained after dispersion of 5 to 10 soil aggregates in a $30 \mathrm{ml}$ solution of $5 \mathrm{~g} \mathrm{l}^{-1} \mathrm{Na}-$ hexametaphosphate, through shaking overnight. The mixture was wet-sieved through a $53 \mu \mathrm{m}$ mesh sieve and weighed after oven drying $\left(55^{\circ} \mathrm{C}\right)$. Sand content previously determined for aggregate stability was removed in order to obtain the final POM fraction $(53 \mu \mathrm{m}<\mathrm{POM}<250$ $\mu \mathrm{m})$.

Statistical analyses

The effects of ecosystem type and aggregation pathway on soil physico-chemical properties were assessed by analyses of variance (ANOVA) followed by Tukey's honestly significant difference (HSD) post-hoc test. Each null hypothesis was rejected at $p<0.05$. Heterogeneity and temporal changes in $\mathrm{OM}$ quality (i.e., ontogeny) of soil macroaggregates within each aggregation pathway were assessed with principal component analysis (PCA) of NIR spectra, using first derivatives as spectral preprocessing. The unconstrained ordination of samples obtained with PCA illustrates the power of NIR data for a blind discrimination of samples based on global OM quality, without any a priori assumption on sample classes (Cécillon et al. 2009). All statistical treatments were conducted using R software version 2.7 (R Development Core Team 2008) with the ade4 package for PCA (Chessel et al. 2004). 


\section{Results}

Basic characteristics of Ah horizons along the spatial climate gradient

Despite the shift in vegetation and soil microclimate from PF to BF (Figure 1), Ah horizons were similar for most soil properties assessed along the spatial climate gradient (Table 1). Heterogeneity within all ecosystem types was non-negligible for each soil attribute, especially in EC plots, as revealed by the strong standard deviation of reference data (Table 1). No significant differences could be detected for SOC, $\mathrm{N}_{\mathrm{t}}, \mathrm{NH}_{4}, \mathrm{CEC}, \mathrm{Ca}, \mathrm{Mg}, \mathrm{K}, \mathrm{Na}$, stone, clay, silt, sand content and porosity between ecosystem types. Soil texture varied slightly from silt loam to silty clay loam across plots (Table 1). However, ANOVA tests revealed significant differences for base saturation, $\mathrm{NO}_{3}$ and $\mathrm{pH}$ (Table 1; $\mathrm{p}<0.05$ ). Base saturation was $25 \%$ higher in Ah horizon of $\mathrm{BF}$; and $\mathrm{Ah}$ horizon of $\mathrm{PF}$ was characterized by a higher $\mathrm{pH}(0.5$ unit increase $)$ and $\mathrm{N}-\mathrm{NO}_{3}$ content $\left(2.5 \mathrm{mg} \mathrm{kg}^{-1}\right.$ increase). Furthermore, strong changes in aggregate size distribution were detected along the gradient (Table 1; Figure 2). Macroaggregate content (> $250 \mu \mathrm{m}$ ) was reduced from $96 \%$ and $90 \%$ in Ah horizon of BF and EC, respectively, to $72 \%$ in Ah horizon of PF $(p<0.05)$. This reduction was even more striking when considering the proportion of macroaggregates above $3.15 \mathrm{~mm}$, with $53 \%$ in $\mathrm{BF}, 30 \%$ in EC plots and only $9 \%$ in PF (Figure 2). Biological activity of Ah horizons also strongly varied along the spatial climate gradient. During the sampling period, Ah horizons showed an important earthworm activity in BF plots, whereas neither individuals nor indices of earthworm bioturbation could be observed in Ah horizons of PF. Earthworm activity was intermediate in EC plots. 
Visual assessment of soil macroaggregation pathways in contrasted ecosystems

Within the nine research plots that included both aggregate size fractions of Ah horizons (3.15-5 $\mathrm{mm}$ and $5-12.5 \mathrm{~mm}$ ), a total of 79 samples could be isolated under the stereomicroscope.

In the 5-12.5 $\mathrm{mm}$ fraction, we identified eight different macroaggregate types across all research plots (Figure 3), with seven, five and eight categories in BF, PF and EC, respectively. These included young, aged, colonized biogenic (BY, BA, BC) and physicogenic aggregates (PY, PA, PC) as well as APD macroaggregates. One category of macroaggregates, never described in cold mountain soils (fragile rounded aggregates; FRA; Figure 3) was found in Ah horizons of PF and EC. Even though the round shape of FRA resembles biogenic aggregates, we hypothesized that due to weak stability, they were generated by physical processes like freeze-thaw cycles which characterize the soil microclimate of PF and EC (Figure 1). Biological and physical pathways were well-balanced in BF (35\% biogenic and $54 \%$ physicogenic aggregates) and EC (49\% of biogenic and $43 \%$ physicogenic aggregates), the remaining being APD in BF, APD and FRA aggregates in EC. Conversely, physical processes overcharacterized soil aggregation in Ah horizons of PF with $61 \%$ of FRA and $5 \%$ of physicogenic aggregates.

The $3.15-5 \mathrm{~mm}$ fraction of Ah horizons was characterized by a smaller diversity of soil aggregates (young and aged biogenic, physicogenic and FRA). Again, biological and physical pathways were equally represented in BF (53\% biogenic and $47 \%$ physicogenic aggregates) and EC (49\% biogenic; and 48\% physicogenic aggregates) with the remaining being FRA aggregates in EC. Conversely, soil aggregates from Ah horizons of PF were entirely formed by physical processes (i.e., $87 \%$ of physicogenic and $13 \%$ of FRA aggregates). 
NIRS assessment of the heterogeneity and the ontogeny of soil macroaggregates

Only samples with a minimum dry weight of $1 \mathrm{~g}$ could be analysed with NIRS. As a consequence, NIRS measurements were performed for 74 out of the 79 macroaggregate samples visually identified. PCA of NIR spectra were carried out by ecosystem type in order to find specific spectral fingerprints for each aggregate categories, and ontogenic trajectories of soil macroaggregation. Factorial projections of NIR spectra of soil aggregates were strongly plot-dependent within each ecosystem type, as depicted in Figure 4a representing spectral fingerprints of soil macroaggregates and Ah horizons samples from BF plots. In order to tackle this analytical problem already pointed out by Velasquez et al. (2007), we tested a new strategy of wavelength selection within NIR spectra inspired from a recent work of Cécillon et al. (2008), so as to remove the plot effect from the PCA. Variable selection was based on the loadings matrix of the PCA. The loadings can be understood as the weights for each original variable (i.e., wavelengths) when calculating the principal components. We removed NIR wavelengths with loadings higher than 0.3 and 0.5 , respectively for the first two principal components which were associated with plot effect. Then, a new PCA was performed with the selected wavelengths. Figure 4 illustrates the usefulness of this strategy on the NIR spectral data of BF. NIRS was found suitable for discriminating soil macroaggregates of biogenic and physical pathways from APD aggregates and whole Ah horizon samples (Figure 4b). Eliminating those spectral outliers from the analysis provided a principal component space in which aggregates from biological and physical pathway could be reasonably separated (Figure 4c). Negative values on the first axis $(76 \%$ of total variance) of the PCA corresponded to $\mathrm{BY}, \mathrm{BC}$ and $\mathrm{PC}$ aggregates, whereas $\mathrm{BA}, \mathrm{PY}$ and $\mathrm{PA}$ aggregates were characterized by positive values on this axis, illustrating the heterogeneity of OM quality of the identified macroaggregate types in a given ecosystem (reasonable results were also obtained for ecotone and pine forests; data not shown).

We also performed PCA of NIR spectra of aggregates from single BF and EC plots (not from single PF plots because too few samples were available), so as to obtain a more detailed representation of the ontogeny of aggregation (Figure 5). Tentative ontogenic trajectories for soil 
macroaggregation based on NIRS are proposed in Figure 5. In BF plots, similar trajectories are observed for biological and physical aggregation pathways (except at the formation of biogenic and physicogenic aggregates) with strong differences between the spectral fingerprints of BY and PY aggregates (Figure 5a). Biological and physical trajectories of macroaggregation were much more distinct in EC plots (Figure 5b). The spectral fingerprint of FRA aggregates was found similar to that of physicogenic aggregates, supporting a physical origin for this macroaggregate type (Figure $5 b)$. These proposed ontogenic trajectories for soil aggregation suggest strong temporal changes in OM quality within both biological and physical pathways of soil macroaggregation, from young aggregates through to aggregates colonized by fine roots.

Basic characteristics of soil macroaggregates along the gradient

We measured six attributes relevant to soil physico-chemical functioning on 70 aggregate samples out of the 79 samples visually identified in Ah horizons of our spatial climate gradient (Table 2).

FRA aggregates had very original physical properties compared to all other ones as revealed by ANOVA tests (Table 2). They were characterized by a lower WSA $(p<0.001)$ and a higher porosity $(p<0.01)$ than all other macroaggregate types. FRA and APD aggregates also showed a lower bulk density than biogenic and physicogenic aggregates $(p<0.001)$ but this characteristic was in fact associated with macroaggregates from PF plots. No differences for SOC, $\mathrm{N}_{t}$ and POM content could be found between aggregation pathways, because of strong variations within each pathway and between ecosystem types. POM content was higher in soil macroaggregates of PF plots than in those of EC and BF plots $(p<0.05)$. $N_{t}$ content was lowest in the macroaggregates of EC plots $(p<0.05)$. No effect of ecosystem type was observed on SOC content of soil macroaggregates. Physical and biological pathways showed similar characteristics for all physico-chemical properties assessed (Table 2). When examining more precisely physical and biological macroaggregation pathways in BF plots, some differences for POM content appeared. BY and BC aggregates were enriched in POM, whereas BA aggregates had a weak POM content $(p<0.05)$. Conversely, POM content of all physicogenic aggregates was almost 
constant. These results could show a preferential way of utilization of BY aggregates by soil microflora, meaning that the stocked POM is cycled more rapidly within these aggregates. However, this trend was not observed in EC plots, under colder conditions.

Regarding soil threats, all macroaggregate types showed similar response for organic matter decline with high SOC content (92 g kg-1 on average) and similar $\mathrm{N}_{\mathrm{t}}$ and POM content (Table 2), suggesting no long-term effect of soil microclimate and vegetation on soil organic matter content of macroaggregates. FRA aggregates, which dominated the aggregate size fraction above $3.15 \mathrm{~mm}$ of Ah horizon of PF plots, were characterized by a very low aggregate stability compared all other macroaggregate types, suggesting a stronger erodibility of Ah horizon in PF plots probably induced by freeze-thaw cycles.

\section{Discussion}

Changes in properties of Ah horizons along the spatial climate gradient

Holding most state factors constant in our design provided a sound basis for assessing the impact of long-term changes in soil microclimate and vegetation, on soil properties and processes. Despite the long-term and strong increase in $T_{s}\left(5.0^{\circ} \mathrm{C}\right)$ from $\mathrm{PF}$ to $\mathrm{BF}, \mathrm{SOC}$ content was constant along the gradient as well as many other properties of Ah horizons, like soil texture. While a constant soil texture might be explained by the homogeneous parent material of the Pellafol site (limestone), a constant SOC content in the Ah horizon contrasts with the much thicker organic layer observed in colder plots which might reflect a greater accumulation of labile SOC in PF and EC, in agreement with Kammer et al. (2009), who reported such SOC accumulation in the organic layer of colder soils, and Hagedorn et al. (2009), who showed increased SOC losses in experimentally warmed soils. But our results support those of Leifeld et al. (2009), who observed no significant trend for SOC concentration in soil horizons deeper than $5 \mathrm{~cm}$ along an elevation gradient. 
Conversely, some properties of Ah horizons were strongly modified from PF to BF, like $\mathrm{N}-\mathrm{NO}_{3}$ or macroaggregate content. Regarding $\mathrm{N}-\mathrm{NO}_{3}$ content of Ah horizons, our results support previously published studies, which have described higher $\mathrm{N}-\mathrm{NO}_{3}$ content and leaching from plots affected by freeze-thaw cycles (Groffman et al. 2001). This increase is thought to be generated by a higher mortality of fine roots under soil frost, which induces a reduction in plant uptake and a strong input of labile OM in soil, thereby increasing nitrification. Denitrification is also usually enhanced, so that freeze-thaw events may turn cold soils into sources of $\mathrm{N}_{2} \mathrm{O}$, a strong greenhouse gas (Groffman et al. 2006; Repo et al. 2009). Our results suggest that frost intensity may control this process, as it only occurs in PF, under the harshest soil frost (Figure 1), and not in EC plots.

Regarding macroaggregate content, Boix-Fayos et al. (1998) showed an increased aggregation on north-facing slopes compared to south-facing slopes in Mediterranean soils due to vegetative differences caused by a colder soil microclimate. Conversely, macroaggregate content was enhanced in warmer plots of our gradient, with a spectacular increase from PF to EC, associated with the small but long-term increase in $\mathrm{T}_{\mathrm{s}}$ of EC plots $\left(+0.7^{\circ} \mathrm{C}\right)$. These results suggest a strong temperature sensitivity of soil aggregation process at low temperatures. The increased macroaggregation under milder soil microclimate along our gradient was linked to higher earthworm activity, which underlines the role of earthworm bioturbation in the formation of soil structure (Brêthes et al. 1995; Lavelle and Spain 2001). The occurrence of bioturbation in warmer plots could reflect either a direct or an indirect effect of soil temperature on earthworms (soil microclimate may indirectly control earthworm activity through changes in the quality of above and below-ground $\mathrm{OM}$ inputs, leading to contrasted humus forms under different vegetation cover; Aerts 2006). Therefore, our results and those of Boix-Fayos et al. (1998), suggest the existence of optimal temperature and vegetation conditions for soil aggregation in mountain ecosystems. 
NIRS as an operational tool for assessing soil macroaggregation dynamics

A wide diversity of macroaggregate types, differing in their origin and their age could be visually identified on the Pellafol site. NIR spectra of aggregates can be considered as global fingerprints of their OM quality (Joffre et al. 2001; Hedde et al. 2005). Using a specific method for processing NIR spectral fingerprints (wavelength selection based on the loadings matrix of the PCA), we could overcome the plot effect and point out heterogeneities in the OM quality of various macroaggregates types in each ecosystem, as previously shown by Hedde et al. (2005) and Velasquez et al. (2007). In addition, ecosystem-specific ontogenic trajectories for soil macroaggregation could be proposed for the first time, based on this spectral classification of aggregates. Such trajectories illustrate temporal changes in $\mathrm{OM}$ quality of soil macroaggregates from their formation through to their colonization by fine roots. These results with NIRS may open the way for further investigations of detritus dynamics in soils, as claimed by Moore et al. (2004). However, as our technique failed to classify similar soil macroaggregate types from different ecosystems, further developments of NIR spectral processing remain.

Functional implications of soil macroaggregation along the spatial climate gradient

The proportion of biological and physical pathway of aggregation varied significantly along our spatial climate gradient. The slight increase in $T_{s}$ (and decrease in frost intensity) from PF to EC increased soil macroaggregate stability and strongly enhanced the contribution of the biological pathway to soil macroaggregation in both aggregate size fractions we investigated. Long-term warming of seasonally frozen soils it seems could thus improve their resistance to erosion through enhancing biological macroaggregation. This result corroborates previous studies which reported an increased erodibility of soils subjected to freeze-thaw cycles (Groffman et al. 2006; Kværnø and Øygarden 2006).

Regarding POM content of soil macroaggregates, the depletion observed in BA aggregates from BF plots may indicate a priming effect of earthworms on microbial decomposition during casts 
formation (Lavelle and Spain 2001). BY aggregates (young earthworm casts) are enriched in POM and intestinal mucus, which stimulate microbial respiration and may lead to depletion in POM content of BA aggregates. New inputs of fresh organic matter are further provided by fine roots in BC aggregates, enhancing their POM content. Such priming effects are not observed in soil biogenic macroaggregates of EC plots because of their colder microclimate.

We observed a decrease in POM content of macroaggregates from warmer plots (BF and EC, compared to PF), similar to reports by Link et al. (2003) and Leifeld et al. (2009), albeit no depletion in their SOC content could be detected along the gradient. A possible explanation for this result might be that increased temperature in Ah horizons may transfer increased amounts of SOC to more stable soil C pools, probably because of accelerated physico-chemical stabilization reactions (Jones and Donnelly 2004). We suggest that enhanced biological process like microbial respiration in warmer plots may counterbalance this phenomenon, thereby stabilizing SOC content.

\section{Conclusion}

Climate change in mountain regions could increase the intensity, frequency and duration of soil frost through the alteration of snowpack depth. Using an original spatial climate gradient on limestone scree slopes, which simulated various soil microclimate conditions, we showed a strong response of soil aggregation processes to the experimental design. We observed profound changes in the heterogeneity and the temporal dynamics of soil macroaggregates, reflecting modification of their OM quality. These changes in soil macroaggregation dynamics were associated with modifications of certain soil attributes of Ah horizons related to soil threats. Our results did not provide evidence for SOC content decline under warmer conditions, albeit a decrease in labile SOM pool was observed. Conversely, we identified a potentially harmful effect of changing climate on mountain soils: increased soil frost may lead to strong decreases in soil biological macroaggregation and soil structural stability, thereby enhancing soil erodibility. 


\section{Acknowledgements}

This work was supported by the French Agency for Environment and Energy Management (ADEME) and Cemagref. Authors are grateful to participants of the conference "Mountain soils under a changing climate and land-use" (WSL, Birmensdorf, Switzerland, 6-8 March 2008) organized within the framework of the COST Action 639 (http://www.cost639.net), and to Frank Hagedorn (WSL, Birmensdorf, Switzerland) and two anonymous reviewers, for their valuable comments. Roy V. Rea (University of Northern British Columbia, Canada), is thanked for improving the English of the manuscript.

\section{References}

Aerts R (2006) The freezer defrosting: Global warming and litter decomposition rates in cold biomes. J Ecol 94:713-724.

Amundson R, Jenny H (1997) On a state factor model of ecosystems. BioScience 47:536-543

Asta J, Orry F, Toutain F et al (2001) Micromorphological and ultrastructural investigations of the lichen-soil interface. Soil Biol Biochem 33:323-337

Barthès BG, Roose E (2002) Aggregate stability as an indicator of soil susceptibility to runoff and erosion; validation at several levels. Catena 47:133-149

Becker A, Körner C, Brun JJ et al (2007) Ecological and land use studies along elevational gradients. Mount Res Dev 27:58-65

Blanco-Canqui H, Lal R (2004) Mechanisms of carbon sequestration in soil aggregates. Crit Rev Plant Sci 23:481-504

Boix-Fayos C, Calvo-Cases A, Imeson AC et al (1998) Spatial and short-term temporal variations in runoff, soil aggregation and other soil properties along a Mediterranean climatological gradient. Catena 33:123-138

Brêthes A, Brun JJ, Jabiol B et al (1995) Classification of forest humus forms: a French proposal. Ann Sci For 52:535-546 
Bronick CJ, Lal R (2005) Soil structure and management: a review. Geoderma 124:3-22

Cambardella CA, Elliott ET (1992) Particulate soil organic-matter changes across a grassland cultivation sequence. Soil Sci Soc Am J 56:777-783

Cassagne N, Spiegelberger T, Cécillon L et al (2008) The impact of soil temperature increase on organic matter and faunal properties in a frozen calcareous scree in the French Alps. Geoderma 146:239-247

Cécillon L, Cassagne N, Czarnes S et al (2008) Variable selection in near infrared spectra for the biological characterization of soil and earthworm casts. Soil Biol Biochem 40:1975-1979

Cécillon L, Cassagne N, Czarnes S et al (2009) Predicting soil quality indices with near infrared analysis in a wildfire chronosequence. Sci Total Environ 407:1200-1205

Chessel D, Dufour AB, Thioulouse J (2004) The ade4 package - I: one-table methods. R News $4: 5-10$

Delaloye R (2004) Contribution à l'étude du pergélisol de montagne en zone marginale. PhD Thesis $n^{\circ} 1441$, Fribourg University, Switzerland (in French)

Delaloye R, Reynard E, Lambiel, C et al. (2003) Thermal anomaly in a cold scree slope (Creux du Van, Switzerland). In: Phillips, Springman, Arenson (eds) Proceedings $8^{\text {th }}$ Int. Conf. Permafrost, Zurich, 2003. AA Balkema, pp175-180

Edwards AC, Scalenghe R, Freppaz M (2007) Changes in the seasonal snow cover of alpine regions and its effect on soil processes: a review. Quat Int 162-163:172-181

European Commission (2006) Communication from the Commission to the Council, the European Parliament, the European Economic and Social Committee and the Committee of the Regions: Thematic Strategy for Soil Protection. COM (2006)231 final, Brussels.

FitzPatrick EA (1980) The micromorphology of soils. A manual for the preparation and description of thin sections of soils. Dept. of Soil Science, University of Aberdeen, U.K.

Garten Jr. CT, Post WM, Hanson PJ et al (1999) Forest soil carbon inventories and dynamics along an elevation gradient in the southern Appalachian Mountains. Biogeochem 45:115-145

Garti C (1980) Gorges de la Souloise et contreforts du massif de l'Obiou. Dissertation, DDA Isère, Grenoble (in French) 
Groffman PM, Driscoll CT, Fahey TJ et al (2001) Colder soils in a warmer world: A snow manipulation study in a northern hardwood forest ecosystem. Biogeochem 56:135-150

Groffman PM, Hardy JP, Driscoll CT et al (2006) Snow depth, soil freezing, and fluxes of carbon dioxide, nitrous oxide and methane in a northern hardwood forest. Glob Change Biol 12:17481760

Hagedorn F, Martin M, Rixen C et al (2009) Short-term responses of ecosystem carbon fluxes to experimental soil warming at the Swiss alpine treeline. Biogeochem, in press, DOI $10.1007 / \mathrm{s} 10533-009-9297-9$

Hedde M, Lavelle P, Joffre R et al (2005) Specific functional signature in soil macro-invertebrates biostructures. Funct Ecol 19:785-793

Heimann M, Reichstein M (2008) Terrestrial ecosystem carbon dynamics and climate feedbacks. Nature 451:289-292

Huber UM, Bugmann, HKM, Reasoner MA (eds) (2005) Global change and mountain regions, an overview of current knowledge. Advances in Global Change Research, volume 23, Springer Netherlands

IUSS Working Group WRB (2006) World Reference Base for Soil Resources 2006.

World Soil Resources Reports No. 103, FAO, Rome

Joffre R, Ågren GI, Gillon D et al (2001) Organic matter quality in ecological studies: theory meets experiment. Oikos 93:451-458

Jones MB, Donnelly A (2004) Carbon sequestration in temperate grassland ecosystems and the influence of management, climate and elevated $\mathrm{CO}_{2}$. New Phytol 164:423-439

Kammer A, Hagedorn F, Shevchenko I et al (2009) Treeline shifts in the Ural mountains affect soil organic matter dynamics. Glob Change Biol 15:1570-1583

Krom MD (1980) Spectrophotometric determination of ammonia: a study of a modified Berthelot reaction using salicylate and dichloroisocyanurate. The Analyst 105:305-316

Kuczak CN, Fernandes ECM, Lehmann J et al (2006) Inorganic and organic phosphorus pools in earthworm casts (Glossoscolecidae) and a Brazilian rainforest Oxisol. Soil Biol Biochem 38:553560 
Kueppers LM, Harte J (2005) Subalpine forest carbon cycling: short- and long-term influence of climate and species. Ecol App 15:1984-1999

Kværnø SH, Øygarden L (2006) The influence of freeze-thaw cycles and soil moisture on aggregate stability of three soils in Norway. Catena 67:175-182

Lal R (2005) Forest soils and carbon sequestration. For Ecol Manag 220:242-258.

Lambert A (1967) La formation de glace dans les conduits karstiques, les roches fissurées et les pierriers. Rev Géog Phys Géol Dyn 2:321-324 (in French)

Lavelle P, Spain AV (2001) Soil ecology. Kluwer Academic Publishers, Dordrecht

Legros JP (2007) Les grands sols du monde. Presses Polytechniques et Universitaires Romandes, Lausanne (in French)

Leifeld J, Zimmermann M, Fuhrer J et al (2009) Storage and turnover of carbon in grassland soils along an elevation gradient in the Swiss Alps. Glob Change Biol 15:668-679

Link SO, Smith JL, Halvorson JJ et al (2003) A reciprocal transplant experiment within a climatic gradient in a semiarid shrub-steppe ecosystem: effects on bunchgrass growth and reproduction, soil carbon, and soil nitrogen. Glob Change Biol 9:1097-1105

Matzner E, Borken W (2008) Do freeze-thaw events enhance C and N losses from soils of different ecosystems? A review. Eur J Soil Sci 59:274-284

Moore JC, Berlow EL, Coleman DC et al (2004) Detritus, trophic dynamics and biodiversity. Ecol Let 7:584-600

NF ISO 10390 (2005) Soil Quality, Determination of pH. AFNOR

NF ISO 10694 (1995) Qualité du sol, dosage du carbone organique et du carbone total après combustion sèche (analyse élémentaire). AFNOR

NF ISO 13878 (1998) Soil quality, determination of total nitrogen content by dry combustion ("elemental analysis"). AFNOR NF X 31-107 (2003) Qualité du sol, détermination de la distribution granulométrique des particules du sol, méthode à la pipette. AFNOR

NF X 31-108 (2002) Qualité des sols, détermination des cations $\mathrm{Ca}++, \mathrm{Mg}++, \mathrm{K}+, \mathrm{Na}+$ extractibles par l'acétate d'ammonium, méthode par agitation. AFNOR 
NF X 31-130 (1999) Qualité des sols, méthodes chimiques, détermination de la capacité d'échange cationique (CEC) et des cations extractibles. AFNOR

Pulleman MM, Six J, Uyl A et al (2005) Earthworms and management affect organic matter incorporation and microaggregate formation in agricultural soils. Appl Soil Ecol 29:1-15

R Development Core Team (2008) R: A language and environment for statistical computing. R Foundation for Statistical Computing, Vienna, Austria

Repo ME, Susiluoto S, Lind SE et al (2009) Large $\mathrm{N}_{2} \mathrm{O}$ emissions from cryoturbated peat soil in tundra. Nature Geosci 2:189-192

Rusek J (1985) Soil microstructures - contributions on specific soil organisms. Quaest Entomo $21: 497-514$

Seybold CA, Herrick JE (2001) Aggregate stability kit for soil quality assessments. Catena 44:3745

Six J, Bossuyt H, Degryze $S$ et al (2004) A history of research on the link between (micro)aggregates, soil biota, and soil organic matter dynamics. Soil Till Res 79:7-31

Tisdall JM, Oades JM (1982) Organic matter and water-stable aggregates in soils. J Soil Sci 62:141-163

Topoliantz S, Ponge JF, Viaux P (2000) Earthworm and enchytraeid activity under different arable farming systems, as exemplified by biogenic structures. Plant Soil 225:39-51

Velasquez E, Pelosi C, Brunet D et al (2007) This ped is my ped: visual separation and near infrared spectra allow determination of the origins of soil macroaggregates. Pedobiologia 51: 7587

Young IM, Blanchart E, Chenu C et al (1998) The interaction of soil biota and soil structure under global change. Glob Change Biol 4:703-712. 


\section{Figures}

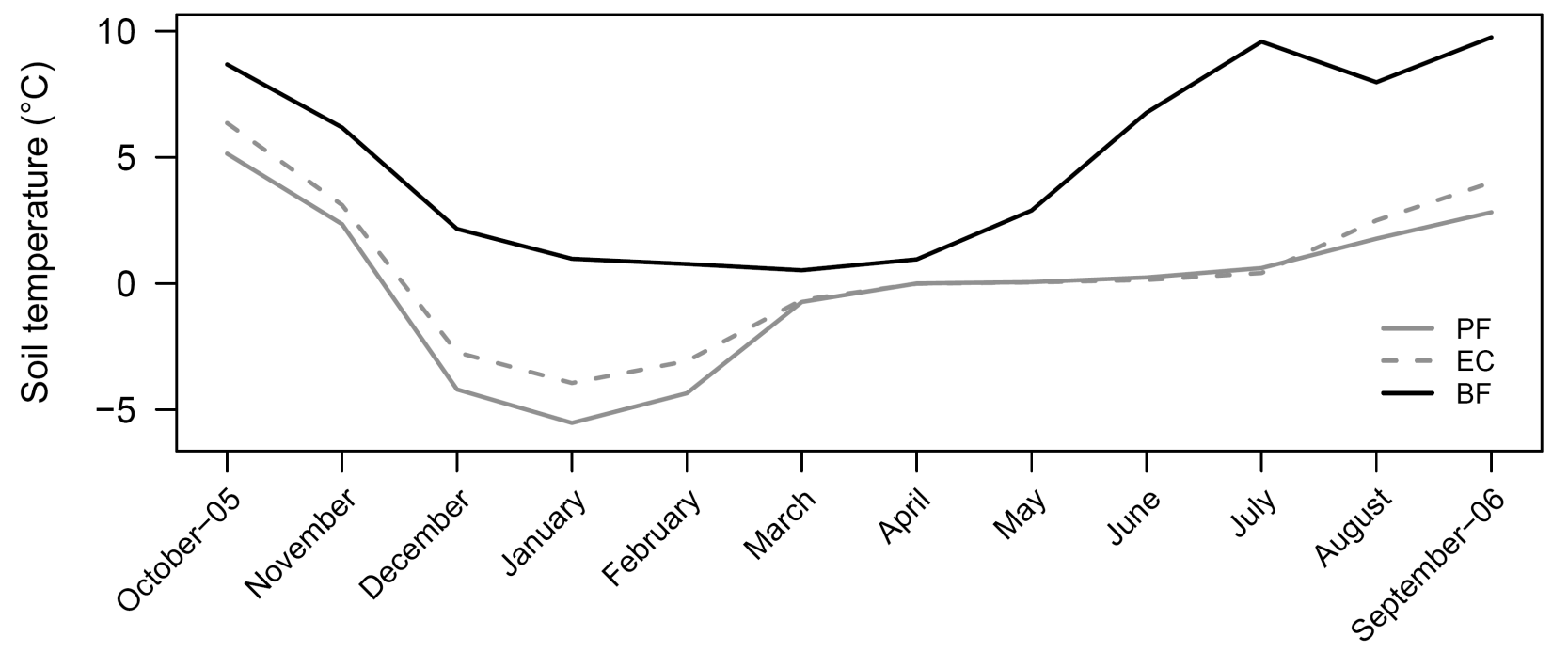

Fig. 1 Monthly average soil temperature in Ah horizons at $30 \mathrm{~cm}$ depth (October 2005-September 2006) in the three ecosystem types of the Pellafol site (Dévoluy, Isère, France)

Abbreviations: $\mathrm{PF}=$ pine forest; $\mathrm{BF}=$ beech-fir forest; $\mathrm{EC}=$ ecotone 


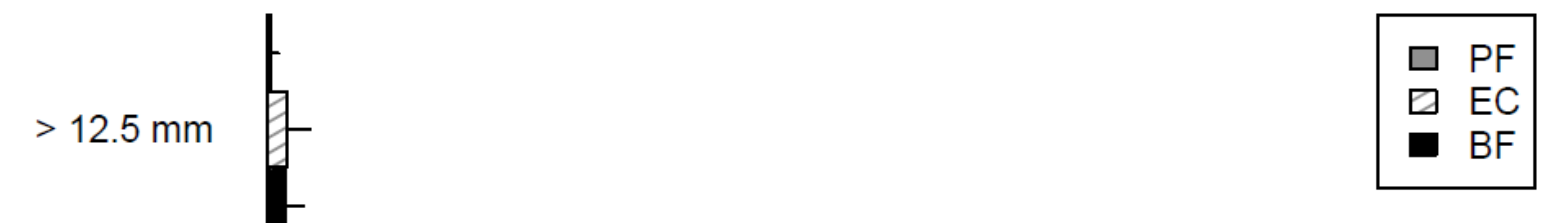

$12.5-5 \mathrm{~mm}$

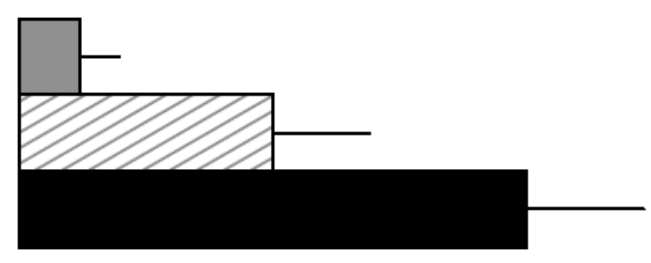

$5-3.15 \mathrm{~mm}$

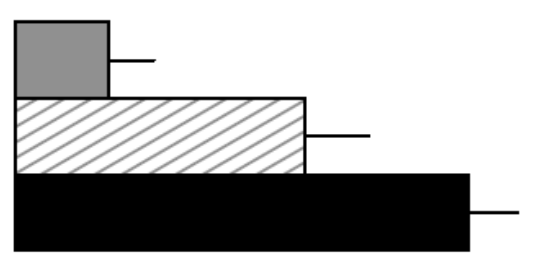

$.15-0.25 \mathrm{~mm}$
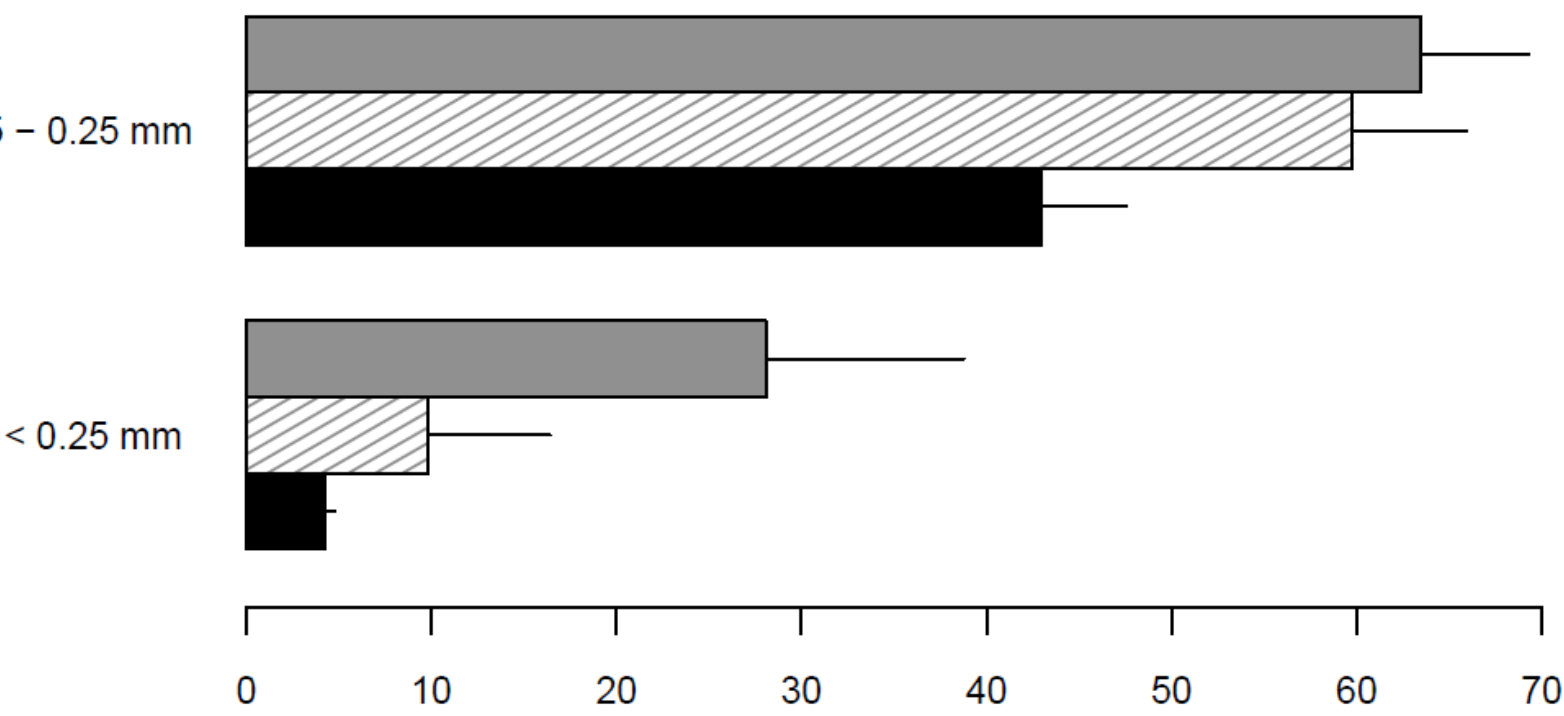

Fig. 2 Mean aggregate size distribution (\%) after dry sieving of Ah horizons along the spatial climate gradient ( $n=3$ per ecosystem type). Segmented lines represent standard deviations Abbreviations: $\mathrm{PF}=$ pine forest; $\mathrm{BF}=$ beech-fir forest; $\mathrm{EC}=$ ecotone 


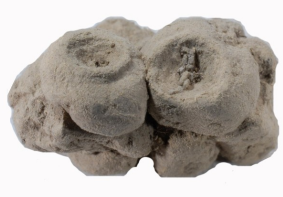

BY

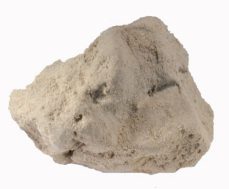

PY

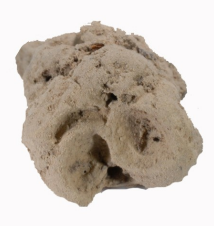

BA

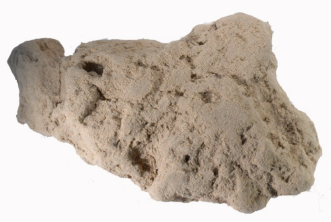

PA

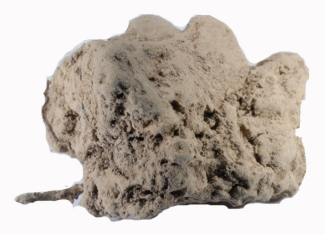

$\mathrm{BC}$

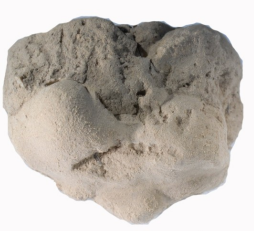

PC

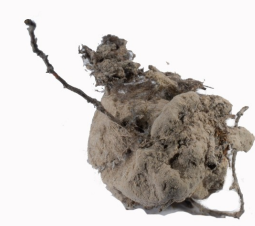

APD

Fig. 3 Examples of the different macroaggregate types separated from the $5-12.5 \mathrm{~mm}$ size fraction: (BY) young biogenic; (BA) aged biogenic; (BC) colonized biogenic; (APD) associated with plant debris; (PY) young physicogenic; (PA) aged physicogenic; (PC) colonized physicogenic; (FRA) fragile rounded aggregates. All aggregates shown here are from BF plots, except FRA which is from PF

Abbreviations: $\mathrm{BF}=$ beech-fir forest; $\mathrm{PF}=$ pine forest 


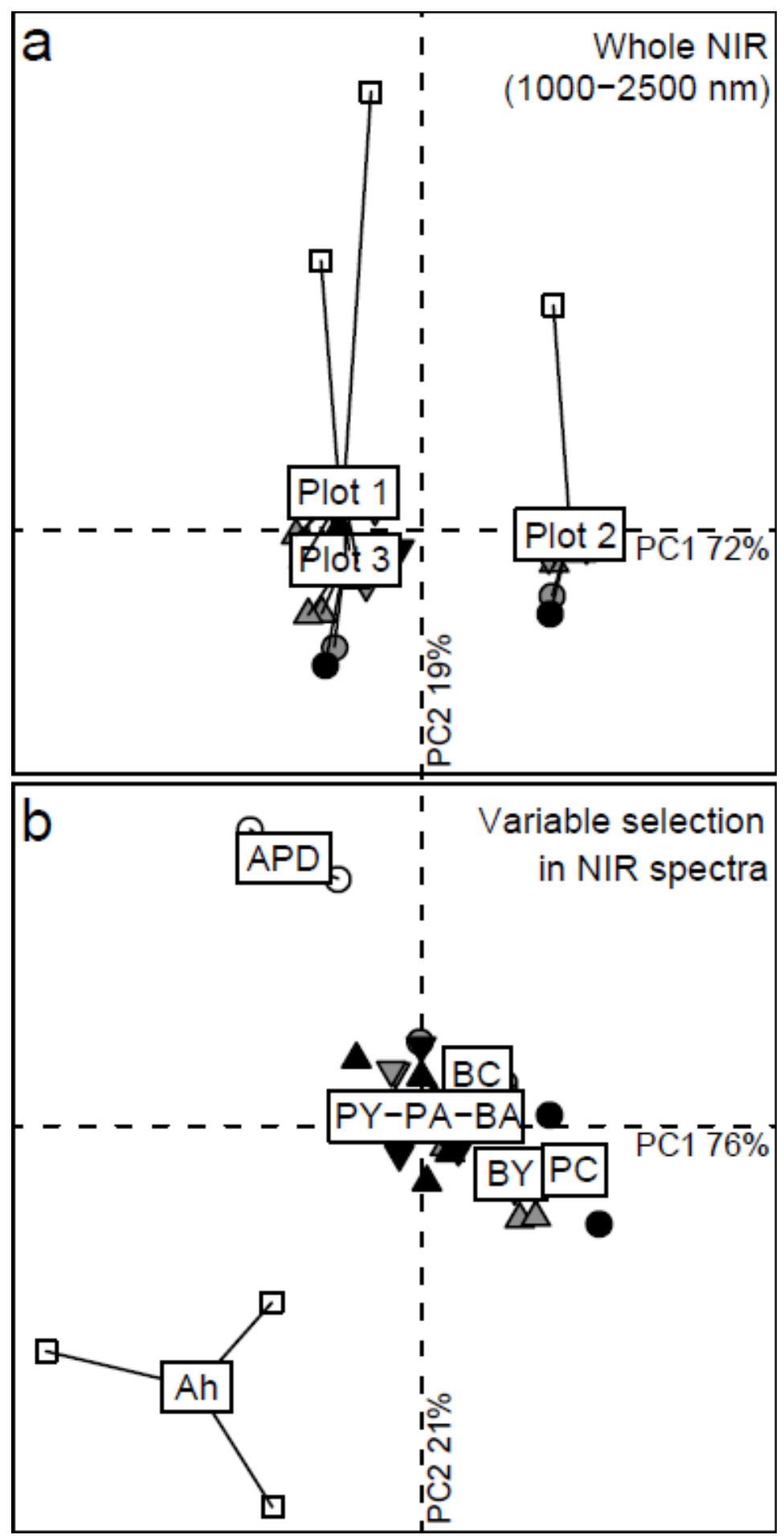

Fig. 4 (a \& b) 


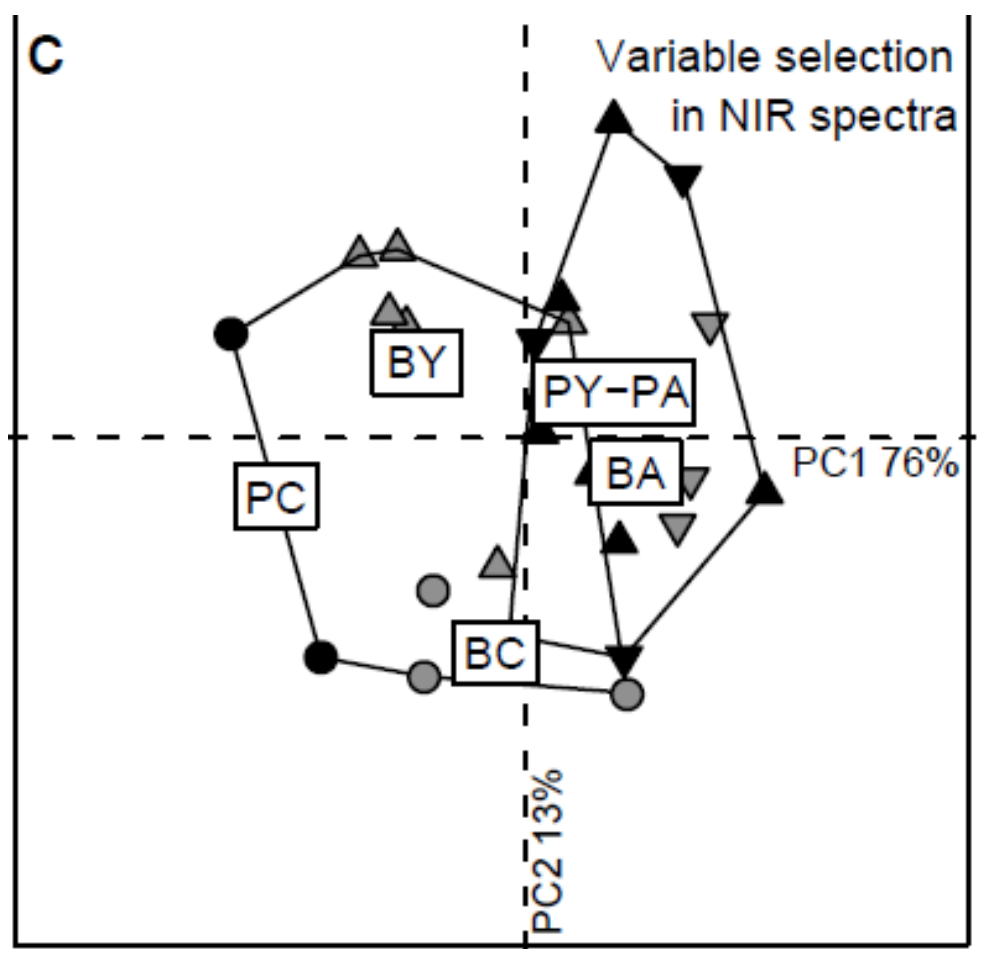

Fig. 4 (c)

Fig. 4 PCA of NIR spectra of all soil macroaggregates and whole Ah horizon samples collected in BF: (a) PCA performed using the full NIR spectrum (1000-2500 nm); (b) PCA performed after one step of wavelength selection within NIR spectra; (c) PCA performed after one step of wavelength selection within NIR spectra, with further removing of Ah horizon and APD samples. Convex hulls indicate two discriminated groups of aggregates

Triangles, inverse triangles and circles correspond respectively to young, aged and colonized aggregates from biological (grey) and physical (black) pathways. White squares, circles and black squares represent respectively Ah horizon, APD and FRA aggregates. Labels indicate gravity centres of research plots, or sample categories (as described in figure 3)

Abbreviations: $\mathrm{PCA}=$ principal component analysis; $\mathrm{NIR}=$ near infrared; $\mathrm{BF}=$ beech-fir forest 

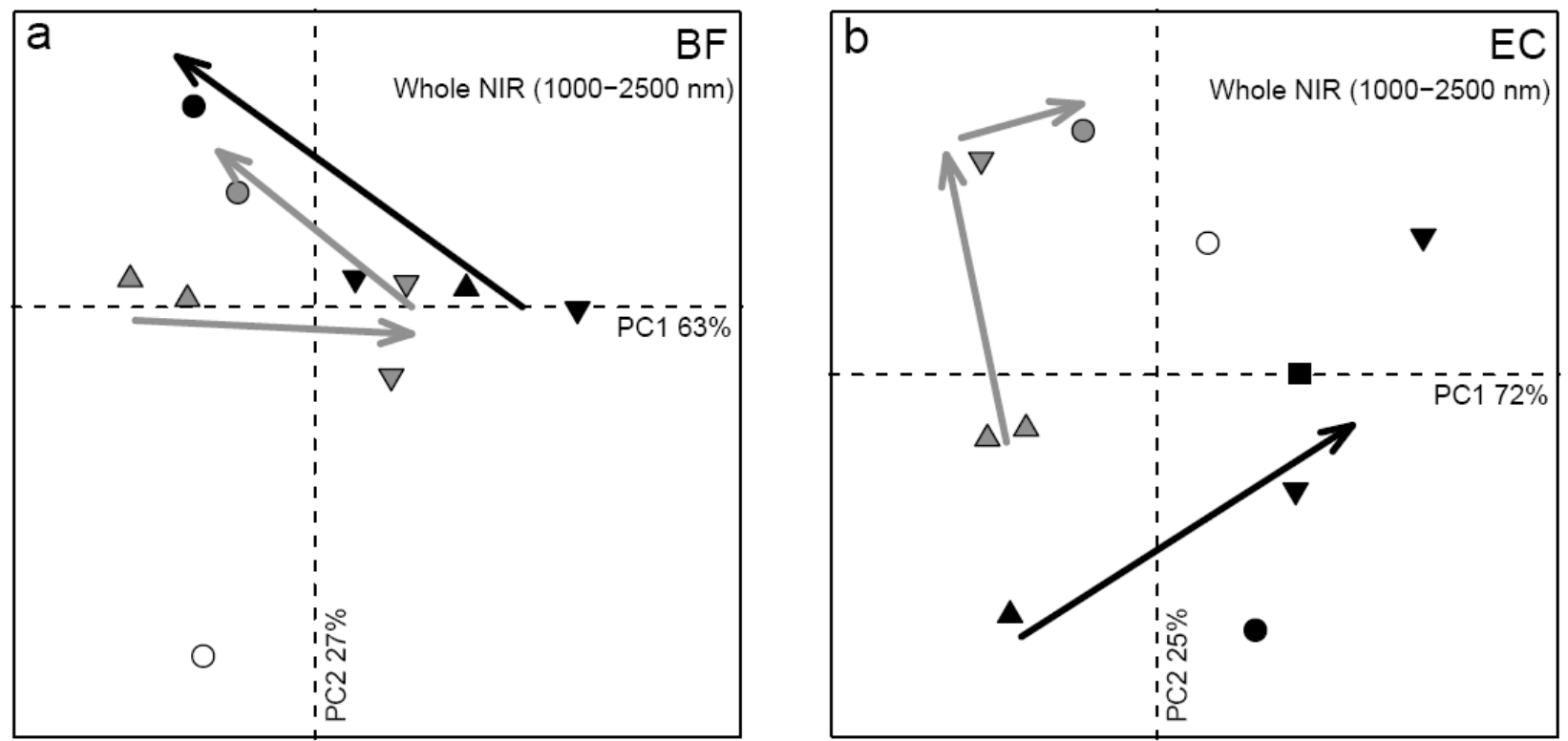

Fig. 5 PCA of NIR spectra of soil macroaggregates from one research plot of BF and EC. Arrows indicate proposed ontogenic trajectories for biological (grey) and physical (black) pathways of soil macroaggregation (similar results were obtained within plots of each ecosystem type). The meaning of symbols is detailed in Figure 4

Abbreviations: $\mathrm{BF}=$ beech-fir forest; $\mathrm{EC}=$ ecotone 


\section{Tables}

Table 1 Summary statistics of basic properties of Ah horizons (composite samples, $n=3$ per ecosystem type)

\begin{tabular}{|c|c|c|c|}
\hline & \\
\hline & PF & EC & BF \\
\hline Soil Property & mean (SD) & mean $(S D)$ & mean (SD) \\
\hline Organic carbon $\left(\mathrm{g} \mathrm{kg}^{-1}\right)$ & $102(24)$ & $106(30)$ & $93(32)$ \\
\hline Total nitrogen $\left(\mathrm{g} \mathrm{kg}^{-1}\right)$ & $4.9(1.1)$ & $4.1(1.0)$ & $4.7(1.2)$ \\
\hline $\mathrm{N}-\mathrm{NO}_{3}\left(\mathrm{mg} \mathrm{kg}^{-1}\right)$ & $4.7(0.9)$ & $1.9(0.4)$ & $2.2(0.8)$ \\
\hline $\mathrm{N}-\mathrm{NH}_{4}\left(\mathrm{mg} \mathrm{kg}^{-1}\right)$ & $7.3(2.0)$ & $8.6(2.9)$ & $8.0(1.1)$ \\
\hline $\mathrm{pH}$ in $\mathrm{H}_{2} \mathrm{O}$ & $7.6(0.1)$ & $6.7(0.5)$ & $7.0(0.2)$ \\
\hline Ca exch. $\left(\mathrm{cmol}+\mathrm{kg}^{-1}\right)$ & $54(10)$ & $47(15)$ & $44(12)$ \\
\hline Mg exch. $\left(\mathrm{cmol}+\mathrm{kg}^{-1}\right)$ & $0.7(0.5)$ & $0.9(0.5)$ & $0.7(0.5)$ \\
\hline K exch. $\left(\mathrm{cmol}+\mathrm{kg}^{-1}\right)$ & $0.11(0.03)$ & $0.13(0.05)$ & $0.12(0.02)$ \\
\hline $\mathrm{Na}$ exch. $\left(\mathrm{cmol}+\mathrm{kg}^{-1}\right)$ & $0.025(0.003)$ & $0.038(0.013)$ & $0.040(0.011)$ \\
\hline CEC $\left(\mathrm{cmol}+\mathrm{kg}^{-1}\right)$ & $55(10)$ & $48(14)$ & $35(8)$ \\
\hline Base saturation (\%) & $100(3)$ & $100(3)$ & $125(16)$ \\
\hline Stone content $(\%)$ & $5(2)$ & $17(14)$ & $20(10)$ \\
\hline Porosity (\%) & $43(3)$ & $44(17)$ & $35(1)$ \\
\hline Macroaggregation (\%) & $72(11)$ & $90(7)$ & $96(1)$ \\
\hline Clay (\%) & $18(3)$ & $25(4)$ & $27(6)$ \\
\hline Silt (\%) & $65(1)$ & $64(2)$ & $63(7)$ \\
\hline Sand (\%) & $17(4)$ & $11(4)$ & $10(1)$ \\
\hline
\end{tabular}

Abbreviations: $\mathrm{SD}=$ standard deviation; exch. = exchangeable; $\mathrm{PF}=$ pine forest; $\mathrm{BF}=$ beech-fir forest; $\mathrm{EC}=$ ecotone 
Table 2 Effect of aggregation pathway on physico-chemical properties of soil macroaggregates

\begin{tabular}{lcccc} 
& \multicolumn{4}{c}{ Soil macroaggregation pathway } \\
\cline { 2 - 5 } & Biological $(\mathrm{n}=29)$ & Physical $(\mathrm{n}=27)$ & APD $(\mathrm{n}=8)$ & FRA (n = 6) \\
\hline Soil Property & mean (SD) & mean (SD) & mean (SD) & mean (SD) \\
\hline Organic carbon $\left(\mathrm{g} \mathrm{kg}^{-1}\right)$ & $87(25)$ & $90(37)$ & $111(30)$ & $92(43)$ \\
Total nitrogen $\left(\mathrm{g} \mathrm{kg}^{-1}\right)$ & $4.1(1.2)$ & $4.2(1.5)$ & $5.0(1.4)$ & $4.7(2.0)$ \\
Porosity (\%) & $38(7)$ & $36(4)$ & $39(6)$ & $46(3)$ \\
Bulk density & $0.65(0.14)$ & $0.61(0.13)$ & $0.47(0.10)$ & $0.45(0.16)$ \\
WSA (\%) & $94(12)$ & $91(13)$ & $93(7)$ & $58(17)$ \\
POM (\%) & $18(7)$ & $18(6)$ & $24(8)$ & $22(10)$ \\
\hline
\end{tabular}

Abbreviations: $\mathrm{SD}=$ standard deviation; $\mathrm{WSA}=$ water stable aggregates; $\mathrm{POM}=$ particulate organic matter 